\title{
ATP and Nitric Oxide Modulate Intracellular Calcium in Isolated Pillar Cells of the Guinea Pig Cochlea
}

\author{
Jong Woo Chung ${ }^{1}$ AND Jochen SCHACHT \\ Kresge Hearing Research Institute, University of Michigan, Ann Arbor MI 48109-0506, USA
}

Received: 10 July 2000; Accepted: 23 April 2001; Online publication: 1 August 2001

\section{ABSTRACT}

Supporting cells in the mammalian cochlea have recently received attention as potential targets of neurotransmitters, neuromodulators, and neurohumoral agents. Calcium homeostasis in Deiters' and Hensen's cells, for example, is regulated by ATP and nitric oxide. We studied the intracellular calcium concentration $\left[\mathrm{Ca}^{2+}\right]_{i}$ in isolated pillar cells of the guinea pig cochlea in response to extracellular ATP and nitric oxide using the fluorescent indicator fluo-3. $\left[\mathrm{Ca}^{2+}\right]_{i}$ increased rapidly and significantly throughout the pillar cell in response to a bolus of ATP or 2-methylthio ATP while $\alpha, \beta$-methylene ATP was ineffective. The response to ATP was inhibited by suramin and Cibacron Blue but not by pyridoxal phosphate 6 -azopheny1-2', $4^{\prime}$-disulfonic acid. This pharmacological profile is consistent with a $\left[\mathrm{Ca}^{2+}\right]_{i}$ increase largely mediated by P2Y receptors. In $\mathrm{Ca}^{2+}$-free medium supplemented with EGTA, the response to extracellular ATP was reduced by $33 \%$, suggesting a contribution of calcium influx to the overall effect. The ATP-induced increase of $\left[\mathrm{Ca}^{2+}\right]_{i}$ was attenuated by NO donors (sodium nitroprusside or diethylamine NONOate), and this attenuation was reversed by KT5823, an antagonist to protein kinase G. The results indicate the involvement of purinergic mechanisms and the nitric oxide/cyclic GMP/protein kinase $G$ pathway in the regulation of $\left[\mathrm{Ca}^{2+}\right]_{i}$ in cochlear pillar cells.

\footnotetext{
${ }^{1}$ Department of Otolaryngology, Asan Medical Center, University of Ulsan, College of Medicine, 388-1, Poongnap-Dong, Songpa-Gu, Seoul, 138-736, Korea.

Correspondence to: Dr. Jochen Schacht $\bullet$ Kresge Hearing Research Institute 1301 East Ann Street • Ann Arbor, MI 48109-0506. Telephone: (734)-763-3572; fax: (734)-764-0014; email: schacht@umich.edu
}

Keywords: calcium, pillar cells, nitric oxide, purinergic receptors

\section{INTRODUCTION}

The so-called supporting cells of the mammalian cochlea, primarily Deiters', Hensen's, and pillar cells, have historically been considered a structural support for the anatomical organization of the organ of Corti. However, recent evidence has shown that these cells may influence auditory transduction in a more active fashion. Deiters' and Hensen's cells are innervated (Burgess et al. 1997; Fechner et al. 1998) and contain receptors for neurotransmitters and neuromodulators such as ATP and acetylcholine (Dulon et al. 1991, 1993; Sugasawa et al. 1996; Matsunobu and Schacht 2001). Furthermore, intracellular calcium $\left[\mathrm{Ca}^{2+}\right]_{i}$ in Deiters' and Hensen's cells is modulated by purinergic receptors and the nitric oxide/cyclic GMP/protein kinase $\mathrm{G}(\mathrm{NO} / \mathrm{cGMP} / \mathrm{cGK}$ ) pathway (Matsunobu and Schacht 2000). The fact that such mechanisms are widespread in the cochlea reinforces the idea that supporting cells are under neuronal and humoral control and participate in homeostatic regulation or feedback signaling in the organ of Corti in both normal and pathological states (Thorne and Housley 1996; Fridberger et al. 1998; Flock et al. 1999).

Pillar cells form a tight junction with the hair cells and maintain the space of Nuel, transmitting stimulusinduced motion between the basilar membrane, the reticular lamina, and the hair cells (Slepecky 1996). Their structural role is emphasized by a large number of organized microfilaments and microtubules in their cell bodies, providing tensile strength. Pillar cells are not innervated but are responsive to neurohumoral 
agents. ATP can induce an inward current by activation of $\mathrm{P} 2 \mathrm{X}$ receptors (Chen et al. 1998), and the presence of soluble guanylate cyclase and protein kinase G (Fessenden and Schacht 1997; Tian et al. 1999; Michel et al. 1999) provides for the possible involvement of NO in the regulation of $\mathrm{Ca}^{2+}$ homeostasis. In this study, we investigate $\left[\mathrm{Ca}^{2+}\right]_{i}$ in isolated pillar cells from the guinea pig cochlea in response to purinergic stimulation and NO.

\section{MATERIALS AND METHODS}

\section{Cell preparation}

Pigmented adult male guinea pigs (200-250 g) were obtained from Elm Hill Breeding Laboratory (Chelmsford, MA). The experimental protocols were in compliance with the guidelines of the National Institutes of Health and the Declaration of Helsinki and were approved by the University of Michigan's Committee on Use and Care of Animals. Animal care was under the supervision of the University of Michigan's Unit for Laboratory Animal Medicine.

Animals were anesthetized with $\mathrm{CO}_{2}$ and decapitated. The cochlea was removed and immersed in Hank's Balanced Salt Solution (HBSS; pH 7.4, $300 \pm$ $2 \mathrm{mOsm}$ ). The bony wall was immediately removed and the stria vascularis and the tectorial membrane were detached. The organ of Corti was then separated from the spiral lamina using a fine metal probe, and pillar cells were dissociated essentially as described for the isolation of outer hair cells (Zenner et al. 1985; Zajic and Schacht 1987). Dissected strips of the organ of Corti were transferred into a $50-\mu \mathrm{L}$ droplet of HBSS. A $50-\mu \mathrm{L}$ aliquot of collagenase (Sigma type IV; $1 \mathrm{mg}$ / $\mathrm{mL}$ in HBSS) was added, and the strips were incubated for $20 \mathrm{~min}$ at room temperature. They were then transferred into a $50-\mu \mathrm{L}$ droplet of fresh HBSS, and gentle trituration of the tissue pieces through a $50-\mu \mathrm{L}$ Hamilton syringe completed the dissociation procedure. The isolated cells were allowed to settle onto the coverslip for $20 \mathrm{~min}$ prior to the experiments.

\section{Calcium imaging}

Changes in $\left[\mathrm{Ca}^{2+}\right]_{i}$ were determined with fluo-3, a fluorescent calcium indicator that increases its fluorescence emission upon binding to nanomolar concentrations of calcium (Minta et al. 1989). One-millimolar stock solutions of the cell-permeant acetoxymethyl ester derivative of fluo-3 (fluo-3/AM) were prepared in dry dimethyl sulfoxide (DMSO) and stored at $-20^{\circ} \mathrm{C}$. For dye loading, cells were incubated for 30 min at room temperature with fluo-3/AM diluted in HBSS to a final concentration of $5 \mu \mathrm{M}$. The cells were maintained in a 50- $\mu \mathrm{L}$ droplet of HBSS on a glass coverslip in a humid chamber. After loading, they were carefully rinsed with fresh HBSS.

Cells loaded with fluo-3 were observed with an inverted microscope (Leitz Fluovert FS) fitted with an epifluorescence system (ArcLamp HBO $100 \mathrm{~W}$, a 450-490-nm bandpass exciter filter, 510-nm dichroic mirror, and a 520-nm barrier filter for excitation and emission, respectively) and Nikon objectives (Plan A $60 / 1.4$ oil, Fluor 100/1.3 oil). The excitation irradiance was reduced by two neutral density filters, attenuating the passage of light by $93.5 \%$ in order to prevent photobleaching. No significant photobleaching was noted with illumination of up to $5 \mathrm{~min}$, the maximal continuous exposure time in this study.

Cell fluorescence was monitored via a Silicon Intensified Target camera (SIT 66, Dage-MTI Inc., Michigan City, IN) and the recorded images were analyzed with an Axon Imaging system using Workbench 2.1 software (Axon Instruments Inc., Foster City, CA). Thirty-two sequential frames (within $1.066 \mathrm{~s}$ ) from the camera were averaged and the fluorescence intensity of the cell images was measured by averaging the pixel radiance value of the cell or segments of the cell.

The amplitude of an evoked response is defined according to Neher and Augustine (1992) as the ratio of the relative fluorescence under test conditions to the fluorescence at time zero of the experiment $(F /$ $\left.F_{0}\right)$. Absolute values for $\left[\mathrm{Ca}^{2+}\right]_{i}$ were estimated by a combined in vitro and in vivo calibration (Kao et al. 1989; Dulon et al. 1990). $\left[\mathrm{Ca}^{2+}\right]_{i}$ was calculated by using the equation $\left[\mathrm{Ca}^{2+}\right]_{\text {free }}=K_{d}\left(F-F_{\min }\right) /\left(F_{\max }-\right.$ $F) . K_{d}$ is the dissociation constant for the fluo-3/calcium complex and $F$ is the observed in situ fluorescence in arbitrary units of intact fluo-3-loaded cells. $F_{\text {max }}$ is the maximum fluorescence and is calculated by using the equation $F_{\max }=\left(F_{\mathrm{Mn}}-F_{\mathrm{bkg}}\right) / 0.2+F_{\mathrm{bkg}}$, where $F_{\mathrm{Mn}}$ is the fluorescence obtained after treatment of the cells with ionomycin $(10 \mu \mathrm{M}$ for $60 \mathrm{~s})$ and $\mathrm{MnCl}_{2}$ (2 $\mathrm{mM}$ for 3-5 min) to saturate the intracellular indicator (Vandenberghe and Ceuppens 1990), and $F_{\text {bkg }}$ is the fluorescent background signal remaining after lysis of the cells with $100 \mu \mathrm{g}$ saponin/mL. The factor 0.2 is the ratio of the fluorescence of $\mathrm{Mn}^{2+}$ saturated fluo-3 to $\mathrm{Ca}^{2+}$-saturated fluo-3. The fluorescence minimum $F_{\min }$ was obtained from the equation $F_{\text {min }}=\left(F_{\text {max }}-F_{\text {bkg }}\right) / 40+F_{\text {bkg }}$, where $1 / 40$ is the ratio of the fluorescence of metal-free fluo- 3 to its $\mathrm{Ca}^{2+}$ complex (Harkins et al. 1993). In vitro fluorescence $F$ values for $\left[\mathrm{Ca}^{2+}\right]_{\text {free }}$ were obtained at different calcium concentrations using the calcium calibration buffer kit (Molecular Probes Inc., Eugene, OR). The data obtained from in situ and in vitro calibration were plotted as $\log \left[\mathrm{Ca}^{2+}\right]_{\text {free }}$ vs. $\log \left\{\left(F-F_{\min }\right) /\left(F_{\max }-F\right)\right\}$. From the $x$-intercept, a $K_{d}$ of $316 \mathrm{nM}$ was calculated, 
a value similar to that found in other reports (Minta et al. 1989; Kao et al. 1989).

\section{Application of purinergic agonists}

The cells were stimulated by a 10-s bolus of ATP, 2methylthio ATP (2MeSATP), or $\alpha, \beta$-methylene ATP ( $\alpha, \beta$-meATP; each in HBSS, $\mathrm{pH} 7.4,298 \mathrm{mOsm})$ applied extracellularly through a glass pipette (Sterile Femtotips, Eppendorf, Hamburg, Germany) connected to a pressure ejector (PLI-100, Medical Systems Corp., Greenvale, NY). The pipette (opening $=0.5 \pm$ $0.2 \mu \mathrm{m}$ ) was placed about $50 \mu \mathrm{m}$ away from the cell. A negative holding pressure was applied after a bolus delivery to prevent diffusion of the solution out of the pipette.

Concentrations of all agents applied in this manner are stated as the concentration in the ejected solution, and the actual concentration reaching the cells was approximated as follows. A solution of $1 \mathrm{mM}$ fluorescein was ejected from the pipette into $50 \mu \mathrm{L}$ of distilled water. By comparison of the resultant fluorescence in the water to a standard curve of fluorescein, the dilution of the injected solution was determined. From the dilution factor, a volume of $32 \pm 5 \mathrm{pL}$ per bolus was calculated. Since the pipette was located $50 \mu \mathrm{m}$ away from the cell, the bolus will diffuse-under the simplest assumption-into a sphere with a radius of $50 \mu \mathrm{m}$ and a volume of $>500 \mathrm{pL}$ before reaching the cell. The agents are thus diluted 10- to 20-fold from their original concentration when they reach the cell, and this concentration will rapidly decrease as the bolus further spreads around the cell.

\section{Application of other agents}

Purinergic antagonists, NO donors, and inhibitors were preincubated with the cells for 5 or 20 min (see the Results section for details) prior to the application of ATP or other agonists. The agents were added to the $50-\mu \mathrm{L}$ droplet containing the cells as $1-\mu \mathrm{l}$ aliquots of $50 \times$ stock solutions. Suramin, PPADS, and Cibacron Blue 3GA were each dissolved in HBSS ( $\mathrm{pH} 7.4$ ) and the osmolality was adjusted to $300 \pm 2 \mathrm{mOsm}$. Sodium nitroprusside (SNP) and diethylamine NONOate (DEA-NO) were also dissolved in HBSS ( $\mathrm{pH}$ 7.4). KT5823 was dissolved in DMSO and diluted in HBSS to obtain the desired concentration (final concentration of DMSO in the bath was $0.06 \%$ ). During the preincubations, cells were not illuminated in order to avoid photobleaching.

\section{Chemical reagents}

Hank's Balanced Salt Solution (HBSS: $1.25 \mathrm{mM} \mathrm{CaCl}_{2}$, $5.55 \mathrm{mM}$ glucose, $0.81 \mathrm{mM} \mathrm{MgSO}_{4}, 0.44 \mathrm{mM} \mathrm{KH}_{2} \mathrm{PO}_{4}$,

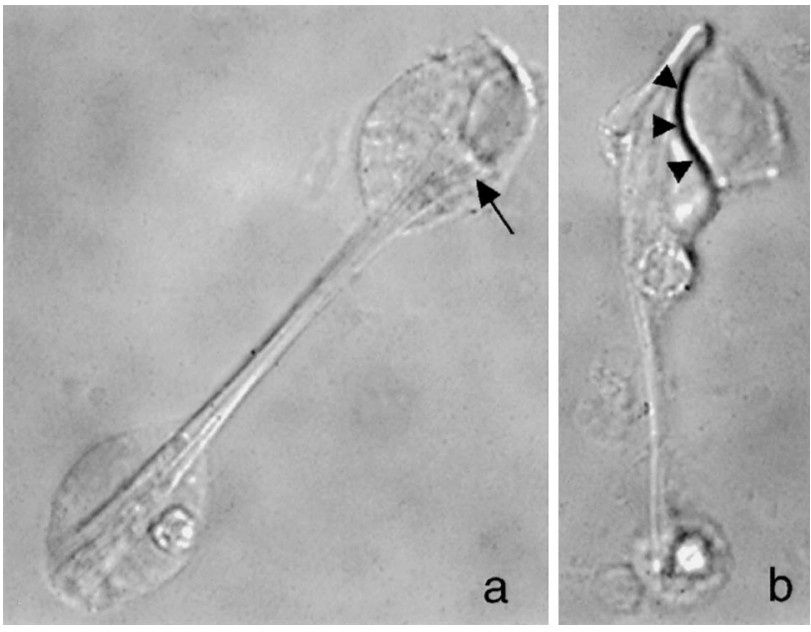

FIG. 1. Isolated outer (a) and inner (b) pillar cells. Cells show distinct microtubules, a clearly delineated cell membrane, and nucleus. Microtubules fan out at the apical portion of the outer pillar cells (arrow). In the inner pillar cell, the microtubules bend toward the site of the outer pillar and outer hair cell, and the apical portion forms a cuplike structure for contact with the outer pillar cell (arrowheads).

$136.9 \mathrm{mM} \mathrm{NaCl}, 0.34 \mathrm{mM} \mathrm{Na}_{2} \mathrm{HPO}_{4}, 5.4 \mathrm{mM} \mathrm{KCl}, 5.0$ $\mathrm{mM}$ sodium HEPES, with osmolality adjusted to $300 \pm$ 2 mOsm with $\mathrm{NaCl}$; $\mathrm{pH}$ 7.4) and $\mathrm{Ca}^{2+}$-free HBSS were purchased from Gibco (Grand Island, NY). Fluo-3/ AM, fluo-3 pentapotassium salt, and calcium-buffered standard solutions were obtained from Molecular Probes Inc. (Eugene, OR), DEA-NO from Cayman Chemical (Ann Arbor, MI), and KT5823 from Biomol Research Laboratories Inc. (Plymouth Meeting, PA). All other reagents were purchased from Sigma Chemical Co. (St. Louis, MO).

\section{Data analysis}

All values are presented as mean \pm SEM. Differences between mean values were evaluated using one-way ANOVA. A $p$ value of $<0.05$ was considered significant.

\section{RESULTS}

\section{Identification and selection of pillar cells}

The pillar cells maintained a distinct shape after isolation (Fig. 1) reminiscent of their morphology in vivo. The cell body of outer pillar cells displayed a round to elliptical shape and contained straight bundles of microtubules spreading at the apex (Tolomeo and Holley 1997). Inner pillar cells were distinguished by their curved microtubule bundles (Tucker et al. 1993). Only cells with a clearly delineated cell membrane, intact microtubules, and nucleus were used.

After isolation, dye loading, and washing with fresh 


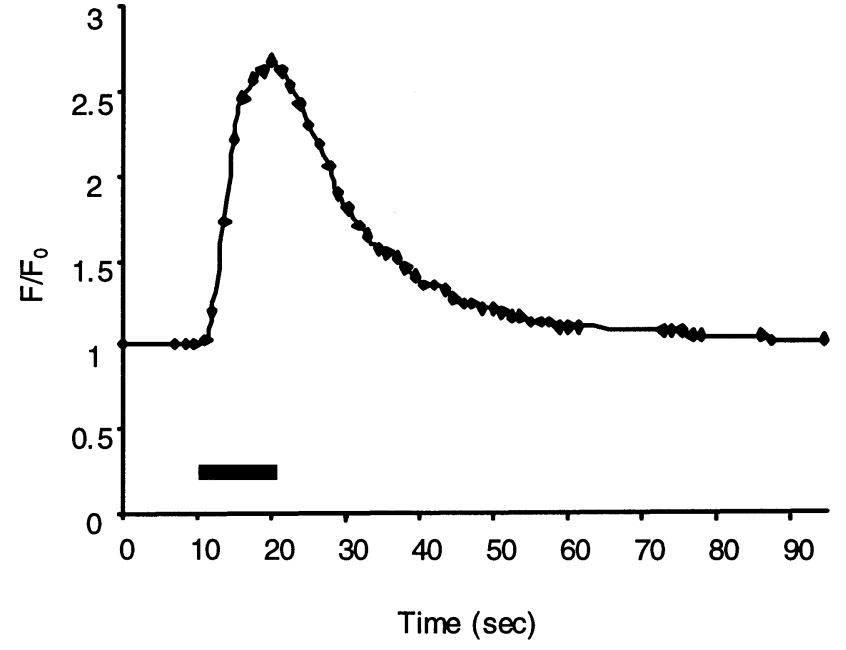

FIG. 2. Response of intracellular calcium to an extracellular bolus of ATP. ATP $(100 \mu \mathrm{M})$ was delivered for $10 \mathrm{~s}$ (bar) to an outer pillar cell. The fluorescence intensity $F / F_{0}$ increased rapidly and returned exponentially to basal levels. Because of the spread of the bolus, the ATP concentration was diluted at least 10 - to 20 -fold before reaching the cell (see Methods section).

HBSS, two cochlea yielded 6-10 inner and outer pillars with outer pillars representing the majority of cells. The initial fluo-3 fluorescence in HBSS indicated resting levels of $\left[\mathrm{Ca}^{2+}\right]_{i}$ from $30 \mathrm{nM}$ upward. Approximately $25 \%$ of the isolated cells were rejected because of an unstable fluorescence baseline or a $\left[\mathrm{Ca}^{2+}\right]_{i}$ exceeding $100 \mathrm{nM}$. Cells included in the studies averaged $49 \pm 3 \mathrm{nM}$ (mean \pm SEM; $n=53$ ) and resting levels were similar in all experimental groups.

\section{$\left[\mathrm{Ca}^{2+}\right]_{i}$ response to ATP}

Fluorescence was significantly increased in all cells $(n=27)$ by the application of a bolus of $100 \mu \mathrm{M}$ ATP. Relative fluorescence $(F)$ increased from $42 \pm 3\left(F_{0}\right)$ to $115 \pm 9\left(F_{\max }\right)$, yielding a ratio of $F_{\max } / F_{0}=2.7 \pm$ 0.1 . Inner and outer pillar cells responded similarly. Of the 27 cells tested, 23 were outer pillar cells giving a response of $F_{\max } / F_{0}=2.78 \pm 0.15$; four inner pillars responded with $F_{\max } / F_{0}=2.80 \pm 0.29$. The agonist 2methylthio ATP (see below) elicited similar responses in 12 outer pillars $\left(F_{\max } / F_{0}=2.90 \pm 0.24\right)$ and 3 inner pillars $\left(F_{\max } / F_{0}=2.95 \pm 0.61\right)$.

Fluorescence began to increase almost immediately after starting the ATP application and attained a maximum $\left(F_{\max }\right)$ at around $9 \mathrm{~s}$ (Fig. 2). Fluorescence then gradually decreased, reaching a plateau after 2-3 min. A response to ATP could be obtained repeatedly in the same cell but the $F_{\max }$ values were successively decreasing $(n=5)$. A bolus application of HBSS alone did not change the fluorescence $\left(F_{\max } / F_{0}=1.00 \pm\right.$ $0.01 ; n=5)$.

The calcium signal elicited by ATP appeared to be
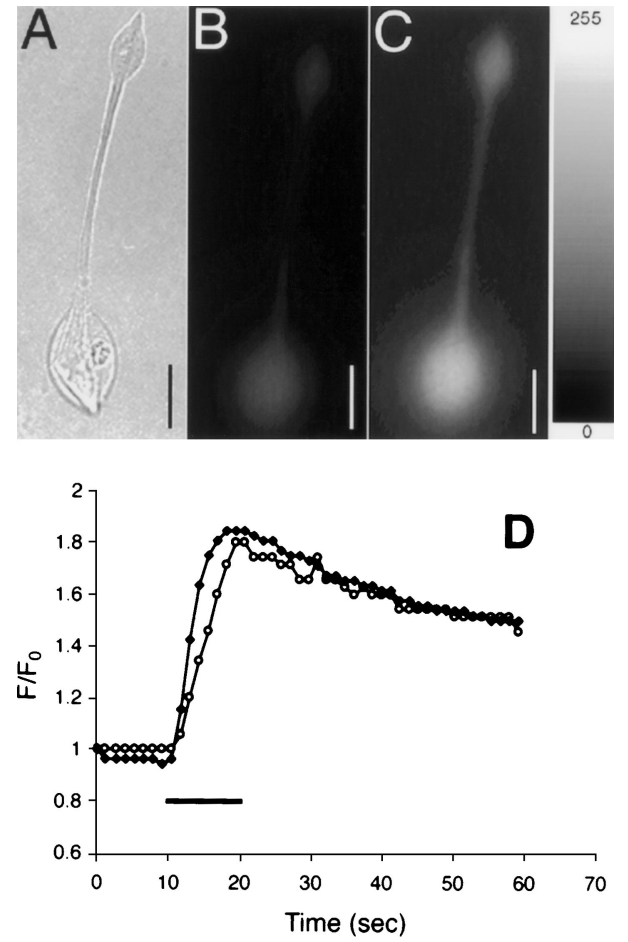

FIG. 3. Base/apex distribution of calcium responses. A. Bright field photomicrograph of an outer pillar cell. B, C. Fluorescence images of the cell at rest $(\mathbf{B})$ and at the maximum of $\left[\mathrm{Ca}^{2+}\right]_{i}$ following ATP stimulation $(\mathbf{C})$. Scale bar $=10 \mu \mathrm{m}$. The calibration bar on the right shows the fluorescence intensity in a gray scale. D. Representative tracing of changes in $\left[\mathrm{Ca}^{2+}\right]_{i}$ in the basal and apical portion of an outer pillar cell following a 10-s application of ATP (bar). Closed symbols, base of the cell; open symbols, apex.

a global response of the cell. There were no obvious local foci nor were there any differences in the kinetics between the basal and apical portion of the cells (Fig. 3). Of five cells studied, two showed a simultaneous rise of fluorescence in base and apex, in one cell the basal increase preceded the apex, and in two the apex preceded the base (Fig. 3D). Likewise, the magnitude of the signal did not differ between base and apex. In two cells the basal and apical maxima were within $\pm 5 \%$, in two cells the apex was higher, in one cell the base was higher yielding an average $F_{\max } / F_{0}$ of $2.68 \pm$ 0.43 in the apex and $2.51 \pm 0.40$ in the base.

\section{$\left[\mathrm{Ca}^{2+}\right]_{i}$ response to ATP in $\mathrm{Ca}^{2+}$-free HBSS}

In $\mathrm{Ca}^{2+}$-free HBSS, resting $\left[\mathrm{Ca}^{2+}\right]_{i}$ was $50 \pm 8 \mathrm{nM}$. Fluorescence increased in 8 out of 10 cells when ATP was applied within 5 min after adding $1 \mathrm{mM}$ ethylene glycol-bis ( $\beta$-aminoethyl ether) $\mathrm{N}, \mathrm{N}, \mathrm{N}^{\prime}, \mathrm{N}^{\prime}$-tetraacetic acid (EGTA) to $\mathrm{Ca}^{2+}$-free HBSS. In responding cells, the $F_{\max } / F_{0}$ ratio was $1.8 \pm 0.3$.

After preincubation of the cells with $1 \mathrm{mM}$ EGTA for $20 \mathrm{~min}$, resting levels of $\left[\mathrm{Ca}^{2+}\right]_{i}$ were significantly reduced to $33 \pm 7 \mathrm{nM}(n=13)$ and ATP no longer 


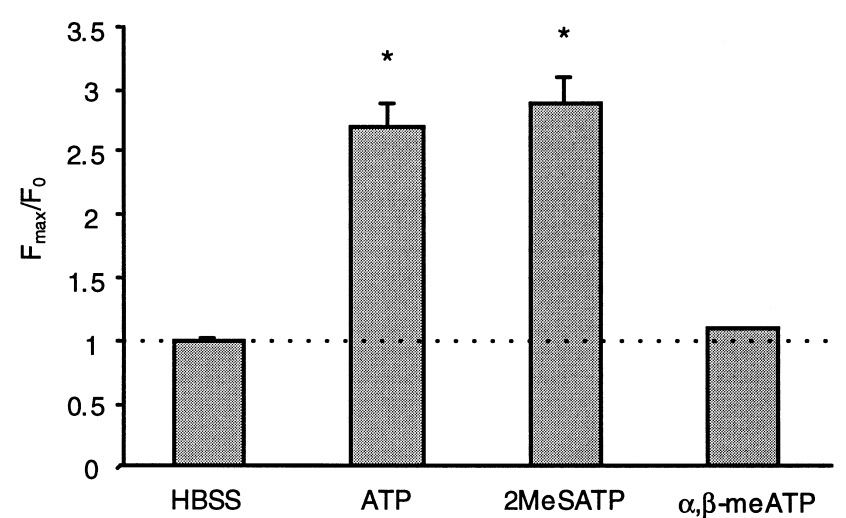

FIG. 4. Calcium response to purinergic agonists. ATP or other agonists were applied as described in the Methods section. The concentrations were $100 \mu \mathrm{M}$ each in the delivery pipette and the bolus was diluted at least 10- to 20-fold before reaching the cell (see the Methods section). The relative maximal fluorescence intensity $\left(F_{\max } / F_{0}\right)$ is shown as mean \pm SEM, and the dashed line indicates the resting fluorescence $\left(F / F_{0}=1\right)$. Asterisks indicate that responses to ATP $(n=27)$ and to 2MeSATP $(n=15)$ differ from HBSS controls $(n=$ $5 ; p<0.05)$. Responses to $\alpha, \beta$-meATP $(n=6)$ do not differ significantly from HBSS controls.

induced a change of fluorescence. When normal HBSS was restituted, an ATP bolus 5 min after restitution elicited a response $\left(F_{\max } / F_{0}=1.8 \pm 0.2, n=3\right)$.

\section{$\left[\mathrm{Ca}^{2+}\right]_{i}$ response to other purinergic agonists}

2-Methylthio ATP (2MeSATP) is a P2 receptor agonist that can induce G-protein-linked intracellular $\mathrm{Ca}^{2+}$ mobilization via P2Y receptors (Burnstock and Kennedy 1985; Fredholm et al. 1997). A 10-s bolus of 2MeSATP $(100 \mu \mathrm{M})$ increased the fluorescence from $F_{0}=46 \pm 4$ to $F_{\max }=133 \pm 11$, resulting in $F_{\max } / F_{0}$ $=2.9 \pm 0.2(n=15$; Fig. 4$)$. The time between the beginning of the bolus and $F_{\max }$ was $9.1 \pm 0.6 \mathrm{~s}$. These responses were not different from those induced by ATP, and cells responded repeatedly with subsequent $F_{\max }$ values continuously decreasing $(n=5)$.

$\alpha, \beta$-Methylene ATP ( $\alpha, \beta$-meATP) has been identified as an agonist of $\mathrm{P}_{2} \mathrm{X}_{1}$ receptors (MacKenzie et al. 1996) and various cloned P2X receptors (Fredholm et al. 1997). When pillar cells were subjected to a 10s bolus of $100 \mu \mathrm{M} \alpha, \beta$-meATP, there was no significant increase of fluorescence $\left(F_{\max } / F_{0}=1.06 \pm 0.03 ; n=\right.$ 6; Fig. 4).

\section{The effect of purinergic antagonists}

The presence of suramin $(500 \mu \mathrm{M})$, an antagonist of both the P2X and P2Y receptor subtypes, inhibited the ATP-induced $\left[\mathrm{Ca}^{2+}\right]_{i}$ increase (Fig. 5). After a 5-min preincubation of isolated cells with suramin, the resting $\left[\mathrm{Ca}^{2+}\right]_{i}(47 \pm 3 \mathrm{nM})$ was not different from the average resting $\left[\mathrm{Ca}^{2+}\right]_{i}$ in HBSS. A 10 -s bolus of 100

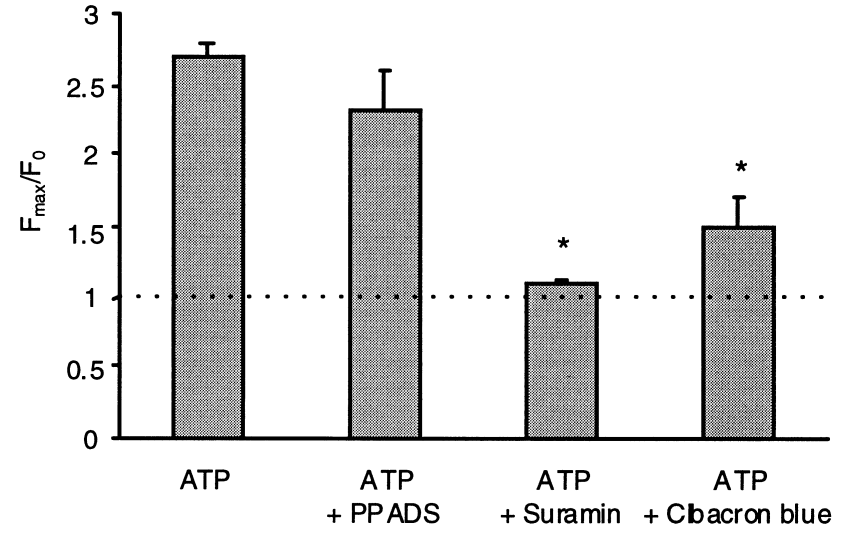

FIG. 5. Calcium response in the presence of antagonists. ATP $(100$ $\mu \mathrm{M})$ was applied to cells preincubated with purinergic antagonists as described in the Methods section, and the relative maximal fluorescence $\left(F_{\max } / F_{0}\right)$ is given as mean \pm SEM. The dashed line indicates the resting fluorescence $\left(F / F_{0}=1\right)$. Asterisks indicate that responses to ATP in the presence of $500 \mu \mathrm{M}$ suramin $(n=6)$ or $100 \mu \mathrm{M}$ Cibacron Blue $(n=7)$ are significantly different from the response to ATP alone $(n=27 ; p<0.05)$. Ten $\mu$ M PPADS $(n=8)$ has no significant effect on the responses to ATP.

$\mu \mathrm{M}$ ATP did not increase the fluorescence $\left(F_{\max } / F_{0}=\right.$ $1.1 \pm 0.01 ; n=6)$. In contrast, $10 \mu \mathrm{M}$ PPADS, a selective P2X antagonist, did not inhibit the response to ATP. After a 5-min preincubation, resting levels of $\left[\mathrm{Ca}^{2+}\right]_{i}$ were unchanged $(47 \pm 5 \mathrm{nM})$ and the cells responded normally to a 10-s bolus of either ATP $\left(F_{\max } / F_{0}=2.3 \pm 0.3 ; n=8\right)$ or 2MeSATP $\left(F_{\max } / F_{0}=\right.$ $2.3 \pm 0.3 ; n=8)$. However, increasing the concentration of PPADS to $100 \mu \mathrm{M}$ eliminated the response to ATP $\left(F_{\max } / F_{0}=1.1 \pm 0.1 ; n=3\right)$.

Cibacron Blue, a selective P2Y antagonist, attenuated the ATP-induced $\left[\mathrm{Ca}^{2+}\right]_{i}$ increase. After a 5-min preincubation of the cells in $100 \mu \mathrm{M}$ Cibacron Blue (resting $\left[\mathrm{Ca}^{2+}\right]_{i}=57 \pm 6 \mathrm{nM}$ ), a 10-s bolus of ATP elicited a significantly lower $F_{\max } / F_{0}$ ratio $(1.5 \pm 0.2$; $n=7 ; p<0.05)$. At $500 \mu \mathrm{M}$, the inhibitory effect was $\operatorname{similar}\left(F_{\max } / F_{0}=1.5 \pm 0.3 ; n=4\right)$. In contrast, 20 $\mu \mathrm{M}$ Cibacron Blue was not effective $\left(F_{\max } / F_{0}=2.4 \pm\right.$ $0.6 ; n=6)$.

\section{The effects of $\mathrm{NO}$ donors}

The effect of nitric oxide on the ATP-evoked $\left[\mathrm{Ca}^{2+}\right]_{i}$ increase was investigated with $\mathrm{NO}$ donors. When the cells were preincubated with either $100 \mu \mathrm{M} S \mathrm{NP}$ or $0.1 \mu \mathrm{M}$ DEA-NO for $20 \mathrm{~min}$ (Maragos et al. 1991; Gryglewski et al. 1989), resting $\left[\mathrm{Ca}^{2+}\right]_{i}$ was $54 \pm 5 \mathrm{nM}$ $(n=9)$ and $56 \pm 6 \mathrm{nM}(n=8)$, respectively, levels not different from the resting $\left[\mathrm{Ca}^{2+}\right]_{i}$ in HBSS. The effect of a subsequent ATP application, however, was significantly attenuated. DEA-NO limited the ATP response to $F_{\max } / F_{0}=1.4 \pm 0.1$ while $\mathrm{SNP}$ was somewhat less effective, reducing the ATP response to $F_{\max } /$ $F_{0}=2.0 \pm 0.2$ (Fig. 6). 


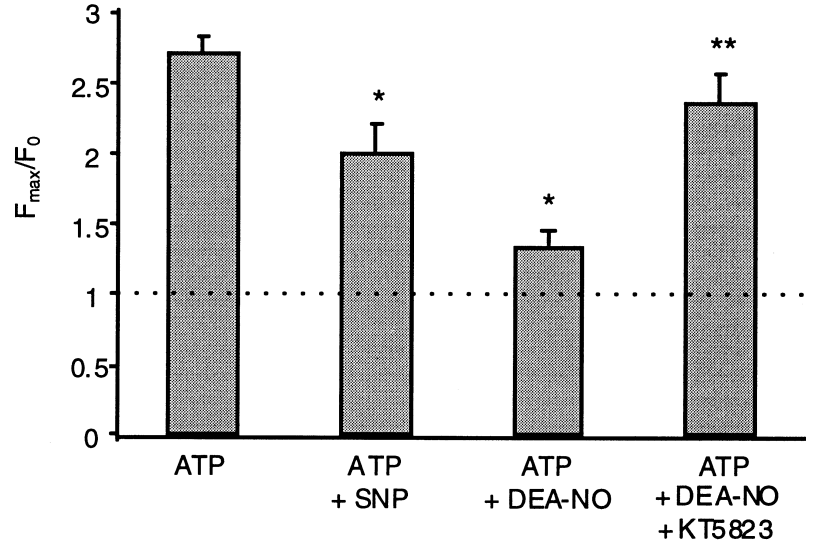

FIG. 6. Responses to ATP in the presence of NO donors and a protein kinase $\mathrm{G}$ inhibitor. ATP $(100 \mu \mathrm{M})$ was applied to cells preincubated with NO donors and a protein kinase $\mathrm{G}$ inhibitor as described in the Methods section. The relative maximal fluorescence intensity $\left(F_{\text {max }} / F_{0}\right)$ is shown as mean \pm SEM. The dashed line indicates the resting fluorescence $\left(F / F_{0}=1\right)$. Asterisks indicate that responses to ATP in the presence of $100 \mu \mathrm{M} \mathrm{SNP}(n=8)$ or $0.1 \mu \mathrm{M}$ DEA-NO $(n$ $=9$ ) are significantly different $(p<0.05)$ from ATP responses in their absence $(n=27)$. Double asterisks indicate that responses to ATP in the presence of $0.1 \mu \mathrm{M}$ DEA-NO plus $1 \mu \mathrm{M} \mathrm{KT5823}(n=6)$ are significantly different from the responses to ATP plus DEA-NO ( $p<$ $0.05)$ but not different from ATP controls $(p>0.05)$

To test the involvement of the cyclic GMP-dependent protein kinase (cGK) pathway in the action of NO donors, the cells were incubated with an inhibitor of cGK. KT5823 is a relatively selective, cell-permeable inhibitor of cGK with a $K_{i}$ of $0.234 \mu \mathrm{M}$ in contrast to its much higher $K_{i}$ for protein kinase A $(4 \mu \mathrm{M})$ and myosin light chain kinase $(>10 \mu \mathrm{M})$ (Kase et al. 1987). When the cells were incubated with $0.1 \mu \mathrm{M}$ DEA-NO in the additional presence of $1 \mu \mathrm{M}$ KT5823, the maximum response to ATP was restored to $2.4 \pm 0.2(n=$ $6)$. The preincubation with DEA-NO in combination with KT5823 had no effect on the resting levels of $\left[\mathrm{Ca}^{2+}\right]_{i}$.

\section{DISCUSSION}

In pillar cells of the guinea pig organ of Corti, $\left[\mathrm{Ca}^{2+}\right]_{i}$ is increased by the extracellular application of ATP, and this response is attenuated by nitric oxide via the $\mathrm{NO} / \mathrm{cGMP} / \mathrm{cGK}$ pathway. This likens the regulation of calcium homeostasis in pillar cells to the mechanisms operating in Deiters' and Hensen's cells and suggests a concerted response of these supporting cells to humoral control.

Purinergic P2 mechanisms are suggested by the efficacy of ATP and the block by suramin, a general P2 receptor antagonist (Hoyle et al. 1990; Van den Abbeele et al. 1996; McMurray et al. 1998). The response to $2 \mathrm{MeSATP}$ and the absence of a response to $\alpha, \beta$-meATP are consistent with an involvement of $\mathrm{P} 2 \mathrm{Y}$ receptors since 2MeSATP is a P2Y agonist while $\alpha, \beta$-meATP is a P2X agonist (Burnstock and Kennedy 1985). Also consistent with the participation of $\mathrm{P} 2 \mathrm{Y}$ receptors are the block of the ATP response by Cibacron Blue and the failure of PPADS to attenuate the effect of ATP at a low concentration. Cibacron Blue is a selective $\mathrm{P} 2 \mathrm{Y}$ antagonist at concentrations between 10 and $500 \mu \mathrm{M}$ (Soediono and Burnstock 1994; Lim et al. 1997; McMurray et al. 1998; Filippi et al. 1999; Shalev et al. 1999). PPADS is a P2X antagonist whose specificity, however, is concentration-dependent. In rabbit vas deferens (Ziganshin et al. 1993), PPADS selectively inhibited the $\alpha, \beta$-meATP-induced contraction at concentrations of $3-30 \mu \mathrm{M}$. At $10 \mu \mathrm{M}$, it was ineffective on pillar cells. Higher concentrations of PPADS (100 $\mu \mathrm{M})$ may result in nonspecific antagonism to ATP (Sima et al. 1997).

Additional support for the involvement of a metabotropic mechanism in the increase in $\left[\mathrm{Ca}^{2+}\right]_{i}$ is the response to ATP in $\mathrm{Ca}^{2+}$-free medium. In this case, calcium should be released from intracellular stores, mediated by an activation of $\mathrm{P} 2 \mathrm{Y}$ receptors coupled to G-proteins and the formation of inositol trisphosphate $\left(\mathrm{IP}_{3}\right)$. With time, EGTA will also deplete intracellular stores (Dulon et al. 1990). This is seen here in the significant decrease of $\left[\mathrm{Ca}^{2+}\right]_{i}$ after a 20-min preincubation, explaining the absence of an ATP response after prolonged EGTA treatment. A mediation of increases in $\left[\mathrm{Ca}^{2+}\right]_{i}$ by $\mathrm{IP}_{3}$ receptors, in turn, is in agreement with the observations that ATP increases inositol phosphate production in the organ of Corti (Niedzielski and Schacht 1992; Ogawa and Schacht 1993, 1994) and that $\mathrm{IP}_{3}$ receptors are present in cochlear supporting cells, including pillar cells (Tian and Schacht 1999).

While our results are consistent with a participation of $\mathrm{P} 2 \mathrm{Y}$ receptors in ATP-induced increases of $\left[\mathrm{Ca}^{2+}\right]_{i}$, other mechanisms may contribute. The diminished response to ATP in $\mathrm{Ca}^{2+}$-free medium might result from a reduction of calcium influx via $\mathrm{P} 2 \mathrm{X}$ receptors or voltage-gated channels. Chen et al. (1998) have shown an ATP-gated inward current in pillar cells which could depolarize the cell and activate voltagegated calcium channels. In this context, the spatial pattern of $\left[\mathrm{Ca}^{2+}\right]_{i}$ increase in pillar cells is reminiscent of global signals like those that can be elicited by voltage-gated channels in smooth muscle cells (Nelson et al. 1990) rather than localized signals that can be observed in outer hair cells in response to ATP (Mammano et al. 1999).

As far as $\mathrm{P} 2 \mathrm{X}$ receptors are concerned, the pharmacological characteristics of $\mathrm{P} 2 \mathrm{X}$ receptor subtypes are too complex to rule out their involvement at this point 
(Fredholm et al. 1997; Kunapuli 1998; North and Surprenant 2000). For example, the $\mathrm{P} 2 \mathrm{X}_{4}$ receptor subunit could not be inhibited by PPADS, and $\alpha, \beta$-meATP evoked a current that was only $13 \%$ of the response to ATP in oocytes expressing both $\mathrm{P}_{2} \mathrm{X}_{4}$ and $\mathrm{P}_{2} \mathrm{X}_{6}$

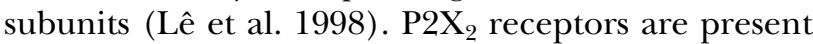
in the apical portion of pillar cells (Housley et al. 1999) where they may contribute to local cation fluxes such as may be involved in the ATP-activated endocochlear shunt (Housley 1998; King et al. 1998). From the sum of our results (and in the absence of precise information on the distribution of ATP receptor subtypes and ion channels along pillar cells), we speculate on multiple pathways involved in $\left[\mathrm{Ca}^{2+}\right]_{i}$ increases in pillar cells with a significant contribution by $\mathrm{P} 2 \mathrm{Y}$ receptors.

The NO/cGMP/cGK pathway, as we have previously shown in Deiter's and Hensen's cells (Matsunobu and Schacht 2000), antagonizes the response to ATP in pillar cells. The fact that the protein kinase $\mathrm{G}$ inhibitor KT5823 reverses the suppressive action of $\mathrm{NO}$ on $\left[\mathrm{Ca}^{2+}\right]_{i}$ suggests that the mechanism of action of $\mathrm{NO}$ is linked to protein kinase $\mathrm{G}$, the final kinase in the pathway. The presence of this pathway in pillar cells is also consistent with the localization of the participating enzymes soluble guanylate cyclase and protein kinase G in these cells (Fessenden and Schacht 1997; Tian et al. 1999). The mechanism by which the calcium signal is attenuated remains speculative since protein kinase G may phosphorylate several relevant target proteins. An inhibition of $\mathrm{Ca}^{2+}$ release from internal $\mathrm{Ca}^{2+}$ stores would directly antagonize a P2Y-mediated calcium increase and is compatible with one of the known actions of protein kinase $\mathrm{G}$, a phosphorylation of $\mathrm{IP}_{3}$ receptors (Komalavilas and Lincoln 1994; Tertyshnikova et al. 1998). Protein kinase G also regulates the activity of several types of calcium channels (Meriney et al. 1994; Sumii et al. 1997; Yao et al. 2000), an action that might contribute to its overall effect. Finally, calcium export via a $\mathrm{Ca}^{2+}$ pump can be activated by protein kinase G (Vrolix et al. 1988).

The regulation of intracellular calcium levels by both purinergic receptors and NO implies the possibility of neurohumoral regulation in pillar cells and raises the question of the physiological significance of calcium mobilization in these structures. The microtubules produce shear resistance and stiffness in outer pillar cells (Tolomeo and Holley 1997). In inner pillar cells, the microtubules follow the curvature of the cell toward the outer pillar and outer hair cell (Tucker et al. 1993). Small changes in the elasticity of the microtubules would have a great impact on the micromechanics of the basilar membrane. However, microtubules in these cells are primarily long-lived and stable and may not undergo cycles of polymerization and depolymerization that could underlie a cytoskeletal rearrangement (Slepecky et al. 1995). On the other hand, the stability and architecture of microtubules are also controlled by crosslinking that is regulated by microtubule-associated proteins (MAPs) (Olmsted 1991; Dhamodharan and Wadsworth 1995; Gamblin et al. 1996). The activity of MAPs, in turn, can be regulated by calcium-dependent phosphorylation (Quinlan and Halpain 1996; Sato-Harada et al. 1996; Pettit and Fay 1998). We therefore speculate that purinergic stimulation and the subsequent rise in $\left[\mathrm{Ca}^{2+}\right]_{i}$ change the stiffness of pillar cells and that this response can be modulated by NO. In combination with a similar effect on calcium mobilization in Deiters' cells, ATP and NO could be major modulators of the micromechanical properties of the basilar membrane.

\section{ACKNOWLEDGMENT}

This research was supported by program project grant DC02982 from the National Institutes on Deafness and Other Communication Disorders, National Institutes of Health.

\section{REFERENCES}

Burgess BJ, Adams JC, NADOL JB JR. Morphologic evidence for innervation of Deiters' and Hensen's cells in the guinea pig. Hear. Res. 108:74-82, 1997.

Burnstock G, Kennedy C. Is there a basis for distinguishing two types of P2-purinoceptors? Gen. Pharmacol. 16:433-440, 1985.

Chen C, Skellett RA, Fallon M, Bobbin RP. Additional pharmacological evidence that endogenous ATP modulates cochlear mechanics. Hear. Res. 118:47-61, 1998.

DHAMODHARAN R, WADSWORTH P. Modulation of microtubule dynamic instability in vivo by brain microtubule associated proteins. J. Cell. Sci. 108:1679-1689, 1995.

DULON D, ZAJIC G, SCHACHT J. Increasing intracellular free calcium induces circumferential contractions in isolated cochlear outer hair cells. J. Neurosci. 10:1388-1397, 1990.

Dulon D, MOLLARD P, ARAN JM. Extracellular ATP elevates cytosolic $\mathrm{Ca}^{2+}$ in cochlear inner hair cells. Neuroreport 2:69-72, 1991.

Dulon D, MOATAZ R, MollaRd P. Characterization of $\mathrm{Ca}^{2+}$ signals generated by extracellular nucleotides in supporting cells of the organ of Corti. Cell Calcium 14:245-254, 1993.

Fechner FP, Burgess BJ, Adams JC, Liberman MC, Nadol JB Jr. Dense innervation of Deiters' and Hensen's cells persists after chronic deefferentation of guinea pig cochleas. J. Comp. Neurol. 400:299-309, 1998.

FESSENDEN JD, SCHACHT J. Localization of soluble guanylate cyclase activity in the guinea pig cochlea suggests involvement in regulation of blood flow and supporting cell physiology. J. Histochem. Cytochem. 45:1401-1408, 1997.

Filippi S, Amerini S, Maggi M, Natali A, Ledda F. Studies on the mechanisms involved in the ATP-induced relaxation in human and rabbit corpus cavernosum. J. Urol. 161:326-331, 1999.

Flock Å, Flock B, Fridberger A, Scarfone E, Ulfendahl M. Supporting cells contribute to control of hearing sensitivity. J. Neurosci. 19:4498-4507, 1999.

Fredholm BB, AbBRACCHIO MP, BRunstock G, Dubyak GR, HARDEN TK, Jacobson KA, Schwabe U, Williams M. Towards a revised nomenclature for $\mathrm{P} 1$ and $\mathrm{P} 2$ receptors. Trends Pharmacol. Sci. 18:79-82, 1997. 
Fridberger A, Flock ^̊, Ulfendahl M, Flock B. Acoustic overstimulation increases outer hair cell $\mathrm{Ca}^{2+}$ concentrations and causes dynamic contraction of the hearing organ. Proc. Natl. Acad. Sci. USA. 95:7127-7132, 1998.

Gamblin TC, NaChmanoff K, Halpain S, Williams RC JR. Recombinant microtubule-associated protein $2 \mathrm{c}$ reduces the dynamic instability of individual microtubules. Biochemistry 35:12576-12586, 1996.

GRYGLEWSKI RJ, KORBUT R, KALECINSKA A, ZEMBOWICZ A. Interaction between stimulators of adenylate and guanylate cyclases in human leukocytes, platelets and arteries. Int. J. Tissue React. 11:269$275,1989$.

HARKINS AB, KUREBAYASHI N, BAYLOR SM. Resting myoplasmic free calcium in frog muscle fibers estimated with Fluo-3. Biophys. J. 65:865-881, 1993

HousLEY GD. Extracellular nucleotide signalling in the inner ear. Mol. Neurobiol. 16:21-48, 1998.

Housley GD, Kanjhan R, Raybould NP, GREENwood D, SALiH SG, Järlebark L, Burton LD, Setz VCM, Cannell MB, Soeller C, Christie DL, Usami S, Matsubara A, Yoshie H, Ryan AF, Thorne PR. Expression of the $\mathrm{P}_{2} \mathrm{X}_{2}$ receptor subunit of the ATP-gated ion channel in the cochlea: Implications for sound transduction and auditory neurotransmission. J. Neurosci. 19:8377-8388, 1999.

Hoyle CHV, KNight GE, Burnstock G. Suramin antagonizes responses to $\mathrm{P} 2$-purinoreceptor agonists and purinergic nerve stimulation in the guinea-pig urinary bladder and taenia coli. Br. J. Pharmacol. 99:617-621, 1990.

Kao JPY, Harootunian AT, Tsien RY. Photochemically generated cytosolic calcium pulses and their detection by fluo-3. J. Biol. Chem. 264:8179-8184, 1989.

Kase H, Iwahashi K, NaKanishi S, Matsuda Y, Yamada K, TAKaHashi M, Murukata C, Sato A, Kaneko M. K-252 compounds, novel and potent inhibitors of protein kinase $\mathrm{C}$ and cyclic nucleotidedependent protein kinases. Biochem. Biophys. Res. Commun. 142:426-440, 1987.

King M, Housley GD, Raybould NP, Greenwood D, Salih SG. Expression of ATP-gated ion channels by Reissner's membrane epithelial cells. Neuroreport 9:2467-2474, 1998.

KomalaVilas P, Lincoln TM. Phosphorylation of the inositol 1, 4, 5-trisphosphate receptor by cyclic GMP-dependent protein kinase. J. Biol. Chem. 269:8701-8707, 1994.

KunaPuli SP. Multiple P2 receptor subtypes on platelets: a new interpretation of their function. Trends Pharmacol. Sci. 19:391394, 1998.

LÊ K-T, Babinski K, SÉGuÉla P. Central P2X $\mathrm{X}_{4}$ and P2X $\mathrm{X}_{6}$ channel subunits coassemble into a novel heteromeric ATP receptor. J. Neurosci. 18:7152-7159, 1998

LIM W, KIM SJ, YAN HD, KIM J. Ca ${ }^{2+}$-channel-dependent and -independent inhibition of exocytosis by extracellular ATP in voltageclamped rat adrenal chromaffin cells. Pflügers Arch. 435:3442, 1997.

Mackenzie AB, Mahaut-Smith MP, Sage SO. Activation of receptor-operated cation channels via $\mathrm{P}_{2} \mathrm{X}_{1}$ not $\mathrm{P} 2 \mathrm{~T}$ purinoceptors in human platelets. J. Biol. Chem. 271:2879-2881, 1996.

mammano F, Frolenkov GI, Lagostena L, Belyantseva IA, Kurc M, Dodane V, CALAVITA A, KaCHAR B. ATP-induced $\mathrm{Ca}^{2+}$ release in cochlear outer hair cells: localization of an inositol trisphosphategated $\mathrm{Ca}^{2+}$ store to the base of the sensory hair bundle. J. Neurosci. 19:6918-6929, 1999.

Maragos CM, Morley D, Wink DA, Dunams TM, SaAvedra JE, Hoffman A, Bove AA, IsaAc L, Hrabie JA, Keefer LK. Complexes of NO with nucleophils as agents for the controlled biological release of nitric oxide: vasorelaxant effect. J. Med. Chem. 34:32423247, 1991.

Matsunobu T, Schacht J. The nitric oxide/cyclic GMP pathway attenuates ATP-evoked intracellular calcium increase in supporting cells of the guinea pig cochlea. J. Comp. Neurol. 423:452461, 2000.

MATSUNOBU T, ScHACHT J. Acetylcholine-evoked calcium increases in Deiters' cells of the guinea pig cochlea suggest $\alpha 9$-like receptors. J. Neurosci. Res. 63:252-256, 2001.

MCMurray G, Dass N, Brading AF. Purinoceptor subtypes mediating contraction and relaxation of marmoset urinary bladder smooth muscle. Br. J. Pharmacol. 123:1579-1586, 1998.

Meriney SD, Gray DB, PILAR GR. Somatostatin-induced inhibition of neuronal $\mathrm{Ca}^{2+}$ current modulated by cGMP-dependent protein kinase. Nature 369:336-339, 1994.

Michel O, Hess A, Bloch W, Stennert E, Su J, Addicks K. Localization of the NO/cGMP-pathway in the cochlea of guinea pigs. Hear. Res. 133:1-9, 1999.

MinTa A, KaO JP, Tsien RY. Fluorescent indicators for cytosolic calcium based on rhodamine and fluorescein chromophores. J. Biol. Chem. 264:8171-8178, 1989.

Neher E, Augustine GJ. Calcium gradients and buffers in bovine chromaffin cells. J. Physiol. 450:273-301, 1992.

Nelson MT, Patlak JB, Worley JF, Standen NB. Calcium channels, potassium channels, and voltage dependence of arterial smooth muscle tone. Am. J. Physiol. 259:C3-C18, 1990.

NiEDZIELSKI AS, SchachT J. P2 purinoceptors stimulate inositol phosphate release in the organ of Corti. Neuroreport 3:273$275,1992$.

North RA, Surprenant A. Pharmacology of cloned P2X receptors. Annu. Rev. Pharmacol. Toxicol. 40:563-580, 2000.

Ogawa K, Schacht J. Receptor-mediated release of inositol phosphates in the cochlear and vestibular sensory epithelia of the rat. Hear. Res. 69:207-214, 1993.

Ogawa K, Schacht J. G-proteins coupled to phosphoinositide hydrolysis in the cochlear and vestibular epithelia of the rat are insensitive to cholera and pertussis toxins. Hear. Res. 74:197203, 1994.

Olmsted JB. Microtubule-associated proteins. Curr. Opin. Cell. Biol. 3:52-58, 1991

Pettit EJ, Fay FS. Cytosolic free calcium and the cytoskeleton in the control of leukocyte chemotaxis. Physiol. Rev. 78:949-967, 1998.

QUINLAN EM, HALPAIN S. Emergence of activity-dependent, bidirectional control of microtubule-associated protein MAP2 phosphorylation during postnatal development. J. Neurosci. 16:76277637, 1996.

Sato-Harada R, Okabe S, Umeyama T, Kanai Y, Hirokawa N. Microtubule-associated proteins regulate microtubule function as the track for intracellular membrane organelle transports. Cell Struct. Funct. 21:283-295, 1996.

Shaley M, Staerman F, Allain H, Lobel B, Saiag B. Stimulation of $\mathrm{P} 2 \mathrm{Y}$ purinoceptors induces, via nitric oxide production, endothelium-dependent relaxation of human isolated corpus cavernosum. J. Urol. 161:955-959, 1999.

Sima B, WeIr BKA, MAcDonald RL, Zhang H. Extracellular nucleotide-induced $\left[\mathrm{Ca}^{2+}\right]_{i}$ elevation in rat basilar smooth muscle cells. Stroke 28:2053-2059, 1997.

Slepecky NB, Henderson CG, SAHA S. Post-translational modifications of tubulin suggest that dynamic microtubules are present in sensory cells and stable microtubules are present in supporting cells of the mammalian cochlea. Hear. Res. 91:136-147, 1995.

SLEPECKY NB. Structure of the mammalian cochlea. In: Dallos P, Popper AN, Fay RR, (eds.) The Cochlea. Springer-Verlag New York, 1996, 44-129.

Soediono P, Burnstock G. Contribution of ATP and nitric oxide to NANC inhibitory transmission in rat pyloric sphincter. Br. J. Pharmacol. 113:681-686, 1994.

Sugasawa M, Erostegui C, Blanchet C, Dulon D. ATP activates a cation conductance and $\mathrm{Ca}^{2+}$-dependent $\mathrm{Cl}^{-}$conductance in 
Hensen cells of guinea pig cochlea. Am. J. Physiol. 271:C1817C1827, 1996.

Sumit K, Imazu M, Yamakido M, Sperelakis N. Cyclic GMP-dependent protein kinase regulates the L-type calcium current in rat ventricular myocytes. Heart Vess. Suppl. 12:62-65, 1997.

Tertyshnikova S, Yan X, FeIn A. cGMP inhibits $\mathrm{IP}_{3}$-induced $\mathrm{Ca}^{2+}$ release in intact rat megakaryocytes via cGMP- and cAMP-dependent protein kinases. J. Physiol. 512:89-96, 1998.

Thorne PR, Housley GD. Purinergic signalling in sensory systems. Sem. Neurosci. 8:233-246, 1996.

Tian F, SсHACHT J. Localization of inositol triphosphate and ryanodine receptors in the guinea pig cochlea. Assoc. Res. Otolaryngol. Abstr. 22:81, 1999.

Tian F, Fessenden JD, Schacht J. Cyclic GMP-dependent protein kinase-I in the guinea pig cochlea. Hear. Res. 131:63-70, 1999.

Tolomeo JA, Holley MC. Mechanic of microtubule bundles in pillar cells from the inner ear. Biophys. J. 73:2241-2247, 1997.

Tucker JB, Paton CC, Henderson CG, Mogensen MM. Microtubule rearrangement and bending during assembly of large curved microtubule bundles in mouse cochlea epithelial cells. Cell Motil. Cytoskeleton 25:49-58, 1993.

Van den Abbeele T, Tran Ba Huy P, Teulon J. Modulation by purines of calcium-activated non-selective cation channels in the outer hair cells of the guinea-pig cochlea. J. Physiol. 494:77-89, 1996.

VAndenberghe PA, Ceuppens JL. Flow cytometric measurement of cytoplasmic free calcium in human peripheral blood $\mathrm{T}$ lymphocytes with fluo-3, a new fluorescent calcium indicator. J. Immunol. Meth. 127:197-205, 1990.

Vrolix M, Raeymaekers L, Wuytack F, Hofmann F, Casteels R. Cyclic GMP-dependent protein kinase stimulates the plasmalemmal $\mathrm{Ca}^{2+}$ pump of smooth muscle via phosphorylation of phosphatidylinositol. Biochem. J. 255:855-863, 1988.

YaO X, Kwan HY, Chan FL, Chan NW, Huang Y. A protein kinase G-sensitive channel mediates flow-induced $\mathrm{Ca}^{2+}$ entry into vascular endothelial cells. FASEB J. 14:932-938, 2000.

ZAJIC G, SCHACHT J. Comparison of isolated outer hair cells from five mammalian species. Hear. Res. 26:249-256, 1987.

ZENNER HP, ZimmermanN U, SCHMitT U. Reversible contraction of isolated mammalian cochlear hair cells. Hear. Res. 18:127-133, 1985.

Ziganshin AU, Hoyle HV, Bo X, Lambrecht G, Mutschler E, BÄUMERT HG, BRUNSTOCK G. PPADS selectively antagonizes P2Ypurinoreceptor-mediated responses in the rabbit urinary bladder. Br. J. Pharmacol. 110:1491-1495, 1993. 